\title{
Examining the Accuracy of Print Media Representations of Homicide in Australia
}

\author{
Emily Waters, ${ }^{*}$ Christine Bond ${ }^{\dagger}$ and Li Eriksson¥
}

\begin{abstract}
Lethal violence is particularly 'newsworthy', and international research suggests that media representations of homicides provide a distorted depiction of the actual nature and risk of homicides. Understanding media portrayals of homicide is important given the impact crime reporting may have on public opinion and policymaking. However, much of the past research has been conducted in the United States and the United Kingdom. Using a sample of Australian newspaper articles published between 1 July 2008 and 30 June 2012, this study focuses on whether media representations of homicide are consistent with the actual characteristics of homicide in Australia (as reported in the National Homicide Monitoring Program (Bryant \& Cussen 2015) data). This study revealed mixed findings. Although the reporting in the sample was generally inconsistent with official homicide victim and situational characteristics, the reported offender characteristics were similar to the actual characteristics of offenders in Australia.
\end{abstract}

Keywords: $\quad$ media - newspaper - homicide - newsworthy - Australia

\section{Introduction}

News is a social construction. Rather than presenting 'the facts', media outlets deliberately choose to include certain crimes and not others in their crime reporting (Chermak \& Chapman 2007). Homicide (defined as the unlawful killing of a person, including murder and manslaughter: Bryant \& Cussen 2015) is particularly 'newsworthy', and international research suggests that homicides are over-reported in the media (Chermak \& Chapman 2007; Gekoski, Gray \& Adler 2012). ${ }^{1}$ For example, Chermak and Chapman (2007) found that while

* Doctoral Candidate, School of Criminology and Criminal Justice, Griffith University, Mt Gravatt Campus, Mt Gravatt Qld 4122, Australia. Email: emily.waters@griffithuni.edu.au.

$\dagger \quad$ Associate Professor, Griffith Criminology Institute \& School of Criminology and Criminal Justice, Mt Gravatt Campus, Griffith University, Mt Gravatt Qld 4122, Australia. Email: c.bond@griffith.edu.au.

‡ Lecturer, Griffith Criminology Institute \& School of Criminology and Criminal Justice, Southport Campus, Griffith University, Southport Qld 4222, Australia. Email: l.eriksson@griffith.edu.au.

1 'The media' is a broad term encompassing a range of fictional (for example, crime dramatisations) and non-fictional (for example, documentaries) material. This study is concerned with the representation of news in 
homicide accounts for less than one per cent of reported crimes in the United States ('US'), it features in over 15 per cent of crime stories in newspapers. The over-representation of homicide in crime reporting can be explained — at least in part - by the way in which homicides commonly contain characteristics that research suggests editors and journalists use in selecting and writing stories. These assessments reflect 'news values' (such as predictability, simplification, risk, violence or conflict, and graphic imagery) that infer judgements about what will be appealing to the public (Jewkes 2015). However, it is not just that homicide itself is newsworthy as it fits into many of the news values due to its violent, graphic and 'risky' nature. These values also influence which homicides are reported, resulting in a mismatch between the 'reality' of homicide and its representation in the media.

International research also suggests the particular circumstances of homicides that are more likely to reflect these news values. Particular victim, offender and situational characteristics appear to increase the news value of homicides (Hong 2008; Lundman 2003; Peelo et al. 2004). For example, research shows that homicides involving children and the elderly, female victims and strangers are more likely to be reported in the media (Buckler \& Travis 2005; Gruenewald, Chermak \& Pizarro 2013; Johnstone, Hawkins \& Michener 1994; Peelo et al. 2004; Pritchard \& Hughes 1997; Sorenson, Manz \& Berk 1998).

However, the research to date has examined media reporting of homicide in the US and the United Kingdom ('UK'), with little research on how homicides are reported in Australia. Although homicide is a rare occurrence in Australia (1.07 per 100,000 people) (Bryant \& Cussen 2015), whether its portrayal by media outlets is distorted (and which features are misrepresented) is still an important issue. Regardless of its rarity compared to other nations, how lethal violence is portrayed in the Australian news media has important implications for public perceptions of safety and, in turn, criminal justice policymaking. Given that the media is a key source of information for the public (Beckett \& Sasson 2003; Duwe 2000), it is not surprising that the portrayal of crime in the media has been linked to increased fear of victimisation (Grabosky 1995; Gruenewald, Pizarro \& Chermak 2009; Reiner 2002). Public perceptions of crime and fear of victimisation may in turn increase receptiveness to tough-oncrime policies, although the effect may be small (Roberts \& Indermaur 2007; Scheingold 1991).

Media representations of crime can also influence public policy as policymakers sometimes use media coverage to determine what the public opinion is concerning crime (Beckett \& Sasson 2003). In Australia, recent examples include the various statutes passed concerning so-called 'one-punch homicides'. The enactment of such laws in the Northern Territory, Western Australia and New South Wales (for example, increased sentencing penalties for violent offending by intoxicated persons, and mandatory minimum sentences), is a political response to the strong media coverage of the tragic deaths of young men caused by unprovoked assaults by an unknown intoxicated assailant (Quilter 2014). These Australian examples highlight the influence of media representations of homicide on public opinion and, subsequently, on policy enactment. This is highly concerning if media outlets do not provide an accurate depiction of homicide in Australia, and may lead to inappropriate policy and legal responses. Thus, given the role that the media can play in influencing fear of crime, public opinion and public policy, understanding the portrayal of homicide in Australian media is important. 


\section{Prior empirical research on media representations of homicides}

Common explanations for the over-reporting of particular victim, offender and situational characteristics of homicides, or crimes more generally, include the rarity of the phenomenon, ideal victim/stereotypical offender characteristics, and news values. Scholars who apply a rarity framework suggest that the more uncommon or unusual the homicide, the more it will be perceived as newsworthy (Gruenewald, Pizarro \& Chermak 2009; Johnstone, Hawkins \& Michener 1994; Lundman 2003; Pritchard \& Hughes 1997). Other scholars have argued that homicides that involve an 'ideal' victim (for example, those who are blameless and vulnerable, or not known to their offender/s) are more likely to be included in news coverage (Christie 1986; Gruenewald, Chermak \& Pizarro 2013). Jewkes (2015) suggests that there are 12 news values that assist journalists and editors when judging whether a story appeals to the public and is consequently newsworthy. These are threshold, predictability, simplification, individualism, risk, sex, celebrity or high status persons, proximity, violence or conflict, visual spectacle, or graphic imagery, children, and conservation ideology and political division (Jewkes 2015). What these explanations have in common is that they recognise that particular combinations of victim, offender and situational characteristics raise the newsworthiness of a homicide, and result in a greater likelihood of its reporting by the media.

Previous international research has identified a range of victim, offender and situational characteristics related to the reporting of lethal violence (Buckler \& Travis 2005; Gruenewald, Pizarro \& Chermak 2009; Johnstone, Hawkins \& Michener 1994; Lundman 2003; Peelo et al. 2004; Sorenson, Manz \& Berk 1998). Although there is a general pattern, there remains some contradictory empirical evidence for the 'newsworthiness' of some of these characteristics.

\section{Victim characteristics}

Research provides inconsistent results about the role of sex and race/ethnicity of the victim on the likelihood of a homicide being reported in the media. Most studies from the US and the UK find that newspapers more frequently report homicides involving female victims than those involving male victims (Johnstone, Hawkins \& Michener 1994; Peelo et al. 2004; Pritchard \& Hughes 1997; Sorenson, Manz \& Berk 1998), despite official homicide statistics consistently showing that males are more at risk of being shomicide victims than females (Buckler \& Travis 2005; Sorenson, Manz \& Berk 1998). Further, in the US, studies also show that homicides involving white victims are more likely to be covered by print media compared to Hispanic or black victims (Johnstone, Hawkins \& Michener 1994; Paulsen 2003; Sorenson, Manz \& Berk 1998), yet victims of homicide are more likely to be Hispanic or black as opposed to white (Johnstone, Hawkins \& Michener 1994; Paulsen 2003; Sorenson, Manz \& Berk 1998). However, more recent international research suggests that the sex and the race/ethnicity of the victim may not matter. In the US, Schildkraut and Donley (2012) examined the reporting of homicides in The Baltimore Sun in 2010 to identify the factors that contributed to newsworthiness for victims. They found that the sex and race of the victims were not important factors to determine whether a homicide was included in print media. Furthermore, in a study of English and Welsh reporting of homicides, Peelo et al. (2004) found that the ethnicity of the victim was not an indicator of whether a homicide would be included in print media coverage. Thus there may have been a shift in whether the sex and race/ethnicity of the victim determines if a homicide is likely to be included in print media coverage. At the very least, there is no clear consensus that victim sex and race influence newsworthiness, independently of other features of the homicide. 
Research examining the age of the victim has provided more consistent results, suggesting that the age of the victim determines whether a homicide is included in print media coverage. Peelo et al. (2004) examined the nature of homicide reporting by examining three newspapers in the UK from 1993-97 and found that when victims are young children, but not infants, the homicide is more likely to be reported in the media. This finding is supported by other studies that have found increased media coverage when homicides involve children or elderly people as victims regardless of national context (Pritchard \& Hughes 1997; Sorenson, Manz \& Berk 1998). For example, Pritchard and Hughes (1997), in a study of two Milwaukee newspapers, found the most consistent predictor of a homicide being covered in those newspapers was that the victim was a child or elderly. Gekoski, Gray and Adler (2012) found similar results using a different methodology: questionnaires to reporters asking their opinion on which types of homicides they considered most newsworthy. They found that 80 per cent of respondents considered homicides involving children to be among the most newsworthy homicides.

The final main characteristic examined in past research is the number of victims. Studies have consistently found that the presence of multiple victims predicts reporting by the media (Gruenewald, Pizarro \& Chermak 2009; Johnstone, Hawkins \& Michener 1994; Paulsen 2003). For example, Paulsen (2003) found that 87 per cent of homicide incidents involving multiple victims were reported in the Houston Chronicle compared with only 68 per cent of homicide incidents involving one victim. Other research has also found the presence of multiple victims to be the strongest predictor of the reporting of a homicide (Johnstone, Hawkins \& Michener 1994; Paulsen 2003).

\section{Offender characteristics}

Similar to the research examining the newsworthiness of victim characteristics, international studies provide inconsistent findings regarding offender sex and race. Previous research found homicides involving male offenders with female victims received more coverage in print media (Johnstone, Hawkins \& Michener 1994). Similarly, examining homicides reported in print media between 1997 and 2005, Gruenewald, Pizarro and Chermak (2009) incidents involving male offenders received longer media coverage than those involving female offenders. In contrast, Peelo et al. (2004) found that the sex of the offender and the ethnicity of the offender were not indicators on whether a homicide would be included in print media coverage. Thus, there appears to be no clear consensus in the prior research as to whether the sex and race of the offender determines if a homicide is likely to be included in print media coverage.

Other characteristics, including number of offenders and offender age, are shown consistently by international research to impact the perceived newsworthiness of a homicide. For instance, the greater the number of offenders involved, the more likely it is that the homicide will receive print media coverage (Gruenewald, Chermak \& Pizarro 2013; Paulsen 2003). Paulsen (2003) found that 77 per cent of homicide incidents involving multiple offenders were reported in the Houston Chronicle compared to only 68 per cent of those incidents that involved one offender. In terms of offender age, Peelo et al. (2004) found that young (under 16) and elderly (over 75) offenders of homicide were more likely to be reported in print media.

\section{Situational characteristics}

There are also characteristics relating to the situational circumstances that determine the news value of a homicide, including motive, victim-offender relationship, weapon use and location of the homicide. Peelo et al. (2004) found that homicides with a sexual motive and homicides where the offender had no apparent motive are more likely to be reported in print media. 
In addition, research has shown that when the victim and offender were strangers, it was more likely to be reported (Buckler \& Travis 2005; Gruenewald, Chermak \& Pizarro 2013; Peelo et al. 2004; Sorenson, Manz \& Berk 1998). Situations involving guns receive more media coverage (Gruenewald, Chermak \& Pizarro 2013) than the use of non-firearm weapons (Gruenewald, Pizarro \& Chermak 2009; Sorenson, Manz \& Berk 1998). Research has also suggested that the type of neighbourhood where the homicide was committed can impact newspaper coverage. For example, in a study of homicide in LA County during 2007, Petersen (2016) found that homicides in disadvantaged black and Latino neighbourhoods were less likely to be included in media coverage than homicides in white neighbourhoods. Furthermore, Johnstone, Hawkins and Michener (1994) and Sorenson, Manz and Berk (1998) found that homicides that occurred in wealthier neighbourhoods were more newsworthy.

\section{The current study's aim}

If certain victim, offender and situational characteristics are overrepresented in the media compared to its actual incidence according to official statistics, then the general public is provided with an inaccurate and distorted representation of the true characteristics of homicide, which, in turn, may have an effect on public opinion and policymaking (Beckett \& Sasson 2003; Duwe 2000). As reviewed above, there is some empirical support in the international literature for the inaccurate representation of homicide in the media, although there is disagreement on why it occurs, whether because a homicide is newsworthy, the victim and offender characteristics are rare, or the homicide involves an ideal victim and stereotypical offender.

While prior research has suggested that the media provides a distorted view of homicide, most of this research has been conducted in the US or the UK. There has been little research examining whether media reporting provides an accurate depiction of homicide characteristics in Australia. Some notable exceptions exist, such as research examining media representations of violence against women (Morgan \& Politoff 2012) and violence against women and their children (Sutherland et al. 2016), though these studies are limited through their focus on violence involving female victims. Further, some of the research findings provide mixed results, particularly around how sex and race of homicide victims and offenders affect media representations. In other words, it is unclear if the sex and race of victims and offenders will have an impact on whether a homicide is likely to be reported in the media. Adding to this, some prior research is relatively dated (1990s onwards) and media reporting may have changed since these studies were conducted. The current study addresses these gaps by examining whether Australian newspaper media representations of homicide are consistent with the actual characteristics of homicide in Australia.

\section{Method}

\section{Data sources and sample}

This study used two data sources: newspaper articles and official homicide statistics. The newspaper article data consisted of a random sample of 120 Australian newspaper articles published between 1 July 2008 and 30 June 2012. These were sampled from the database Factiva, which is a comprehensive global news source database that covers full text news sources. The search was limited to all regional, state and national Australian newspapers available in Factiva. Broad search terms (homicide, homicides, filicide, lethal violent, murder, 
murders, manslaughter and murdered) were used to identify the population of reports on homicide during the specified period. The initial search resulted in 110,435 newspaper articles identified as relating to homicide. A sample of these articles was selected by using a stratified random sampling method. The newspaper articles were first stratified by the financial year and then randomly selected within each stratum. A sample of 30 newspaper articles per year was selected, with a total sample of 120 newspaper articles. Any article selected that did not relate to homicide incidents (for example, those covering attempted homicide or fictional homicide accounts) or that reported on a homicide that had occurred outside Australia were discarded and a replacement newspaper article was randomly selected from the initial pool. The majority of articles came from state newspapers (58.3 per cent), with 35.8 per cent appearing in regional newspapers and nearly six per cent appearing in national newspapers.

This study focused exclusively on print newspapers, as opposed to other media outlets (for example, television or radio). There were five main reasons for this. First, it allowed for comparisons with international research, as the majority of existing research conducted on media representations of homicide have used newspapers as their data source (Gruenewald, Pizarro \& Chermak 2009; Johnstone, Hawkins \& Michener 1994; Lundman 2003; Paulsen 2003; Peelo et al. 2004). Second, newspapers leave researchable tracks (Lundman 2003), available through databases containing transcribed newspapers. Other broadcasted media in Australia, such as television and radio news, are not as readily available. Third, newspaper articles are often used as the source for television and radio reporting of homicide (Golan 2006; Meyers 1996). Further, research shows that traditional newspapers significantly influence the news agenda of online newspapers, suggesting that traditional newspapers still remain key agenda-setters within media outlets (Hoffman 2006). Finally, print newspaper readership rates in Australia are still relatively high despite the increase in online news subscriptions (Roy Morgan Research 2015). For example, from July 2014 to June 2015, on average, approximately 970,000 people read The Australian, 1,227,000 people read The Courier Mail, 1,549,000 read The Daily Telegraph, and 1,241,000 read The Sydney Morning Herald per week (Roy Morgan Research 2015). These figures suggest that newspapers are still considered an authoritative source of media reporting of news in Australia.

The second data source consisted of official homicide statistics accessed from publicly available data from the Australian Institute of Criminology's National Homicide Monitoring Program ('NHMP') (Bryant \& Cussen 2015). The NHMP has collected information concerning homicides in Australia since 1 July 1989 (Bryant \& Cussen 2015), prior to which there was no systematic information or monitoring of homicide in Australia (Mouzos 2002). The NHMP relies primarily on police offence reports and coronial records, supplemented with police officers' first-hand knowledge of the homicide, data from other government agencies (such as statistical services, homicide squads or major crime units) and press clippings (Mouzos 2002). The data are considered to be comprehensive of homicides in Australia as very few homicides go unreported or undetected (Mouzos 2002), although a 'dark figure' of homicide (for example, hidden bodies, missing people) always remains (Brookman 2005; Mouzos 2002). The NHMP contains information relating to victims, offenders, and situational characteristics of homicide in aggregate data form. The data was accessed through published reports in aggregate form, not in raw data on individual incidents. The data covered the same time period as the newspaper article data, from 1 July 2008 to 30 June 2012. Overall, there were 989 known homicide incidents in Australia during this period.

\section{Coding procedures}

The sample of newspaper articles was coded for victim, offender and situational characteristics. The inclusion of variables was based on past research, while also guided by 
the data availability in the official homicide statistics. Variables coded included: victim age and sex; number of victims; offender age and sex; number of offenders; victim-offender relationship; and mode of death (see below for a full description). Other empirically and theoretically relevant variables (for example, victim and offender ethnicity) generated high levels of missing data and consequently had to be dropped from the study.

Ten per cent of the sample of newspaper articles (12 articles) was randomly selected for inclusion in a pilot study to trial the coding schedule and check for inter-coder reliability, or consistency across the coders (Kraska \& Neuman 2011). Overall, there was 72.5 per cent agreement between the two coders. While some variables had near perfect agreement (for example, victim/offender sex, and the number of victims/offenders), the disparities highlighted the need for revision of the coding rules for some variables. For instance, identifying the mode of death and the relationship between the victim and offender needed further clarification. Once the coding schedule had been amended, the full sample was coded.

\section{Variables}

\section{Victim characteristics}

Three victim characteristics were included: sex of the victim; age of the victim; and the presence of multiple victims. Age was coded into the following categories: 0-9 years, 10-14 years, 15-17 years, 18-24 years, 25-34 years, 35-49 years, 50-64 years, and 65 years plus. These were in accordance with how the NHMP categorised victim age (Bryant \& Cussen 2015). The variable multiple victims was coded as two or more victims in the same homicide incident, also in accordance with the NHMP's classification. The NHMP stated the victim's sex and age and the number of victims as unknown in less than one per cent of homicides. Of the newspaper articles, 8.8 per cent did not state the victim's sex, 30.9 per cent did not state the victim's age, and less than one per cent did not state the number of victims.

\section{Offender characteristics}

Similarly, offender sex, offender age at time of the homicide, and presence of multiple offenders were coded from the news reports. Offender age was coded into the following categories: 0-17 years, 18-24 years, 25-34 years, 35-49 years, 50-64 years, and 65 years plus in accordance with the NHMP categorisation (Bryant \& Cussen 2015). In contrast to victim age, offenders under 18 were grouped together in one category for the purposes of the analysis due to the low number of homicides involving offenders under the age of 18 . The NHMP stated the offender's sex and age as unknown in less than one per cent of homicides. Of the newspaper articles, 12.9 per cent did not state the offender's sex, and 35.3 per cent did not state the offender's age. The variable multiple offenders was operationalised as two or more offenders in the same homicide incident, in accordance with the NHMP (Bryant \& Cussen 2015). The NHMP stated the number of offenders was unknown in less than six per cent of homicides, while the number of offenders was not listed in 13.9 per cent of the newspaper articles.

\section{Situational characteristics}

In accordance with the NHMP (Bryant \& Cussen 2015), victim-offender relationship consisted of three categories: domestic, acquaintance and stranger. Domestic homicides are incidents involving the death of a family member of a person from a domestic relationship. Acquaintance homicides are incidents where the victim and offender knew each other but were not related or living in a domestic relationship. Stranger homicides are incidents where the victim and offender did not know each other. In cases of multiple victims and/or offenders (and consequently multiple relationship types), the relationship was coded as the closest 
known relationship between any one victim and offender pair in the NHMP. In 13.5 per cent of homicide incidents the relationship between the victim and offender was unclassified in the NHMP aggregate data. For the purposes of this analysis, relationship between victim and offender were coded as acquaintance, domestic (known) or other (stranger or relationship unknown).

The final variable is the mode of death. Mode of death was grouped into four categories, based on the NHMP classifications. These are beatings, stab wound, gunshot wound and other. Further classification of mode of death was not possible due to the low numbers in the media reports. The mode of death was inferred from the newspaper article. For example, if an article said that the victim was shot and killed, it is inferred that the mode of death was gunshot wound. However, the mode of death was not identified in 35.8 per cent of the newspaper articles.

\section{Analytic strategy}

The analysis aimed to compare the distribution of selected characteristics of victims, offenders and homicide situations between those reported in the primary data source and the official homicide statistics. As the NHMP contains aggregated data, the newspaper data was weighted by count to determine the percentages (Hinton, McMurray \& Brownlow 2014). Pearson's chi-square test was used to estimate whether there was a difference in the distribution between the two sources, except in the case of two by two tables, which used Yate's Correction for Continuity. Effect size was estimated using the phi coefficient value for two by two tables (Pallant 2013), and Cramer's V for larger tables, to take into account the degrees of freedom (Pallant 2013).

\section{Findings}

\section{Victim characteristics}

Table 1 shows the distribution of victim characteristics (sex, age, multiple victims) coded from the newspaper sample compared to those in the NHMP data. Overall, there were statistically significant differences between the reported victim characteristics in the sample and those in the official data. While nearly half of the sampled newspaper articles included female victims of homicide, only one-third of homicide victims during the time period were female according to the national homicide statistics. Similarly, homicides with multiple victims were over-reported in the sampled newspaper articles compared to the national homicide statistics. The analyses further show statistically significant differences in terms of the age of the victims. Table 1 shows that victims under 24 years old are over-reported in the newspapers sampled, while victims over 25 years old are under-reported. The differences are particularly apparent for young children (aged 0-9).

Table 1: Victim characteristics coded from newspaper articles compared to NHMP data

\begin{tabular}{|c|c|c|c|c|c|c|c|c|c|}
\hline \multicolumn{2}{|c|}{ Victim } & \multirow{2}{*}{$\begin{array}{c}\text { NHMP }^{*} \\
(\mathbf{N}) \\
357\end{array}$} & \multirow{2}{*}{$\begin{array}{c}\begin{array}{c}\text { NHMP } \\
(\%)\end{array} \\
34.00\end{array}$} & \multirow{2}{*}{$\begin{array}{c}\begin{array}{c}\text { Media } \\
\text { (N) }\end{array} \\
59\end{array}$} & \multirow{2}{*}{$\begin{array}{c}\begin{array}{c}\text { Media } \\
\text { (\%) }\end{array} \\
47.60\end{array}$} & \multirow[t]{2}{*}{$\begin{array}{c}\chi^{2} \\
\text { (df) }\end{array}$} & \multirow[t]{2}{*}{$\mathbf{p}$} & \multirow[t]{2}{*}{$\begin{array}{l}\text { Test } \\
(\mathrm{N})\end{array}$} & \multirow[t]{2}{*}{$\begin{array}{c}\text { Effect } \\
\text { size }\end{array}$} \\
\hline Sex & Female & & & & & & & & \\
\hline & Male & 694 & 66.00 & 65 & 52.40 & & & & \\
\hline & Total & 1051 & 100.00 & 124 & 100.00 & $8.40(1)$ & .004 & 1175 & -.09 \\
\hline \multirow[t]{4}{*}{ Age } & $0-9$ & 43 & 4.20 & 16 & 17.00 & & & & \\
\hline & $10-14$ & 17 & 1.70 & 4 & 4.30 & & & & \\
\hline & $15-17$ & 26 & 2.60 & 8 & 8.50 & & & & \\
\hline & $18-24$ & 130 & 12.80 & 19 & 20.20 & & & & \\
\hline
\end{tabular}




\begin{tabular}{|c|c|c|c|c|c|c|c|c|c|}
\hline \multicolumn{2}{|c|}{ Victim } & \multirow{2}{*}{$\begin{array}{c}\text { NHMP }^{*} \\
\text { (N) } \\
225\end{array}$} & \multirow{2}{*}{$\begin{array}{c}\begin{array}{c}\text { NHMP } \\
(\%)\end{array} \\
22.10\end{array}$} & \multirow{2}{*}{$\begin{array}{c}\begin{array}{c}\text { Media } \\
(\mathbf{N})\end{array} \\
11\end{array}$} & \multirow{2}{*}{$\begin{array}{c}\begin{array}{c}\text { Media } \\
\text { (\%) }\end{array} \\
11.70\end{array}$} & \multirow[t]{2}{*}{$\begin{array}{c}\chi^{2} \\
\text { (df) }\end{array}$} & \multirow[t]{2}{*}{$\mathbf{p}$} & \multirow[t]{2}{*}{$\begin{array}{c}\text { Test } \\
(\mathrm{N}) \\
\end{array}$} & \multirow[t]{2}{*}{$\begin{array}{c}\text { Effect } \\
\text { size }\end{array}$} \\
\hline Age & $25-34$ & & & & & & & & \\
\hline & $35-49$ & 317 & 31.20 & 17 & 18.10 & & & & \\
\hline & $50-64$ & 163 & 16.00 & 12 & 12.80 & & & & \\
\hline & $65+$ & 96 & 9.40 & 7 & 7.40 & & & & \\
\hline & Total & 1017 & 100.00 & 94 & 100.00 & $53.32(7)$ & $<.001$ & 1111 & .22 \\
\hline \multirow[t]{3}{*}{ Volume } & $\begin{array}{l}\text { One } \\
\text { victim }\end{array}$ & 945 & 92.60 & 101 & 84.90 & & & & \\
\hline & $\begin{array}{l}\text { Multiple } \\
\text { victims }\end{array}$ & 76 & 7.40 & 18 & 15.10 & & & & \\
\hline & Total & 1021 & 100.00 & 119 & 100.00 & 7.33 (1) & .007 & 1140 & -.09 \\
\hline
\end{tabular}

\section{Offender characteristics}

Table 2 compares the distribution of offender characteristics (sex, age, multiple offenders) coded from the sample with those in the NHMP data. The results show no statistically significant differences for any of the offender characteristics between the homicides reported in the newspaper sample, and the national homicide statistics. This shows that, unlike the victim characteristics, newspaper article reporting of offender sex, offender age, and number of offenders was consistent with the national homicide statistics.

Table 2: Offender characteristics coded from newspaper articles compared to NHMP data

\begin{tabular}{|c|c|c|c|c|c|c|c|c|c|}
\hline \multicolumn{2}{|c|}{ Offender } & $\begin{array}{c}\text { NHMP } \\
(\mathrm{N})\end{array}$ & $\begin{array}{c}\text { NHMP } \\
(\%)\end{array}$ & $\begin{array}{c}\text { Media } \\
(\mathrm{N})\end{array}$ & $\begin{array}{c}\text { Media } \\
(\%)\end{array}$ & $\begin{array}{l}\chi^{2} \\
\text { (df) }\end{array}$ & $\mathbf{p}$ & $\begin{array}{c}\text { Test } \\
(\mathrm{N}) \\
\end{array}$ & $\begin{array}{c}\text { Effect } \\
\text { size }\end{array}$ \\
\hline \multirow[t]{3}{*}{ Sex } & Female & 150 & 13.10 & 19 & 15.70 & & & & \\
\hline & Male & 991 & 86.90 & 102 & 84.30 & & & & \\
\hline & Total & 1141 & 100.00 & 121 & 100.00 & $0.41(1)$ & .519 & 1262 & -.02 \\
\hline \multirow[t]{7}{*}{ Age } & $0-17$ & 54 & 4.90 & 3 & 3.30 & & & & \\
\hline & $18-24$ & 245 & 22.50 & 23 & 25.60 & & & & \\
\hline & $25-34$ & 310 & 28.40 & 17 & 18.90 & & & & \\
\hline & $35-49$ & 346 & 31.70 & 35 & 38.90 & & & & \\
\hline & $50-64$ & 104 & 9.50 & 8 & 8.90 & & & & \\
\hline & $65+$ & 32 & 2.90 & 4 & 4.40 & & & & \\
\hline & Total & 1091 & 100.00 & 90 & 100.00 & $5.51(5)$ & .357 & 1181 & .07 \\
\hline \multirow[t]{3}{*}{ Volume } & $\begin{array}{l}\text { One } \\
\text { offender }\end{array}$ & 785 & 77.70 & 86 & 83.50 & & & & \\
\hline & $\begin{array}{l}\text { Multiple } \\
\text { offenders }\end{array}$ & 225 & 22.30 & 17 & 16.50 & & & & \\
\hline & Total & 1010 & 100.00 & 103 & 100.00 & $1.50(1)$ & .220 & 1113 & -.04 \\
\hline
\end{tabular}

\section{Situational characteristics}

Table 3 compares the distribution of situational characteristics coded from the sampled newspaper articles with those in the NHMP data. Overall, there were statistically significant differences between the reported situational characteristics in the sample and those in the 
official data. As seen in Table 3, the sampled newspaper articles tend to over-report gunshot wounds and under-report knife wounds and beatings as the mode of death.

Table 3: Situational characteristics coded from newspaper articles compared to NHMP data

\begin{tabular}{|c|c|c|c|c|c|c|c|c|c|}
\hline & & $\begin{array}{c}\text { NHMP } \\
(\mathrm{N})\end{array}$ & $\begin{array}{c}\text { NHMP } \\
(\%)\end{array}$ & $\begin{array}{c}\text { Media } \\
(\mathrm{N})\end{array}$ & $\begin{array}{c}\text { Media } \\
(\%)\end{array}$ & $\begin{array}{l}\chi^{2} \\
\text { (df) }\end{array}$ & $\mathbf{p}$ & $\begin{array}{c}\text { Test } \\
(\mathrm{N}) \\
\end{array}$ & $\begin{array}{c}\text { Effect } \\
\text { size }\end{array}$ \\
\hline \multirow[t]{5}{*}{$\begin{array}{l}\text { Mode of } \\
\text { death }\end{array}$} & Beating & 253 & 27.50 & 9 & 11.70 & & & & \\
\hline & $\begin{array}{l}\text { Gunshot } \\
\text { wound }\end{array}$ & 131 & 14.20 & 18 & 23.40 & & & & \\
\hline & Other & 161 & 17.50 & 33 & 42.90 & & & & \\
\hline & $\begin{array}{l}\text { Stab } \\
\text { wound }\end{array}$ & 375 & 40.80 & 17 & 22.10 & & & & \\
\hline & Total & 920 & 100.00 & 77 & 100.00 & $\begin{array}{c}40.52 \\
(3) \\
\end{array}$ & $<.001$ & 997 & .20 \\
\hline \multirow[t]{4}{*}{$\begin{array}{l}\text { Relation- } \\
\text { ship }\end{array}$} & $\begin{array}{l}\text { Acquaint } \\
\text {-ance }\end{array}$ & 366 & 37.00 & 20 & 16.70 & & & & \\
\hline & Domestic & 372 & 37.60 & 33 & 27.50 & & & & \\
\hline & Other & 251 & 25.40 & 67 & 55.80 & & & & \\
\hline & Total & 989 & 100.00 & 120 & 100.00 & $\begin{array}{c}50.33 \\
(3)\end{array}$ & $<.001$ & 1109 & .21 \\
\hline
\end{tabular}

Table 3 further shows that newspaper reporting of victim-offender relationship is not consistent with existing homicide data. Table 3 indicates that over one-third of homicide incidents in Australia involved victims and offenders whose relationship was classified as acquaintance. However, homicides involving acquaintances were reported in only 16.7 per cent of the sampled newspaper articles. Furthermore, more than one-third of homicide incidents in Australia involved victims and offenders whose relationship was classified as domestic. In comparison, this relationship was found in just over one-quarter of the sampled newspaper reports.

\section{Discussion}

The aim of this study was to examine whether Australian newspaper media representations of homicide are consistent with the actual characteristics of homicide in Australia. The analyses revealed mixed findings. While some characteristics of homicide were not consistent with those of actual homicide, others were. Overall, the study found that the sampled newspaper articles were inconsistent with official homicide victim and situational characteristics. However, interestingly, the results also indicated newspaper reporting of homicide provided a relatively accurate depiction of the offender characteristics of homicide in Australia, including sex, age and number of offenders.

\section{Inaccurate depictions of homicide}

The results indicated that certain groups of victims, based on sex, age and number of victims, were over-reported in the newspaper sample. Homicides involving female victims were more likely to be reported in the media. This is consistent with much of the previous literature, which suggests that female homicide victims are over-represented in the media compared to male victims (Boulahanis \& Heltsley 2004; Johnstone, Hawkins \& Michener 1994; Pritchard 
\& Hughes 1997; Sorenson, Manz \& Berk 1998). The apparent newsworthy nature of female victims is consistent with a number of explanatory frameworks. In particular, the concept of rarity and ideal victims may assist in explaining why female victims are more commonly reported on in the media, and thus considered more newsworthy compared to male victims. The rarity framework suggests that if an incident is considered uncommon, it is more likely to be newsworthy and receive media attention (Gruenewald, Pizarro \& Chermak 2009; Johnstone, Hawkins \& Michener 1994; Lundman 2003; Pritchard \& Hughes 1997). The results of this study appear consistent with this explanation given that, statistically, females are less likely than males to be victims of homicide in Australia (Bryant \& Cussen 2015). It has also been suggested that society is more sympathetic towards female victims, and that crimes involving female victims are therefore more likely to be reported in the media (Christie 1986). The notion that females represent the 'ideal' victim compared with males was also supported in this study.

The results also indicated that victims aged under 25 are more likely to be reported by the media. This is particularly true for children between the ages of 0 and 9 . This is consistent with previous literature that found children were more likely to be reported in the media (Peelo et al. 2004; Pritchard \& Hughes 1997; Sorenson, Manz \& Berk 1998). Jewkes (2015) suggests that children are newsworthy subjects. Because being a child victim of homicide is rare compared to an adult victim, this result again supports the concept of rarity. In addition, children are often seen as vulnerable, which is one of the characteristics of the ideal victim (Christie 1986). This could also explain why children were over-represented in this study.

Nevertheless, some results are inconsistent with prior research on victim age. The study found that victims between the ages of 18 and 24 are more likely to be reported in newspaper articles. In fact, elderly victims were slightly under-represented in the findings. This was not seen in previous literature, which found young and elderly victims more likely to be reported in the media as opposed to young adults (Peelo et al. 2004; Pritchard \& Hughes 1997; Sorenson, Manz \& Berk 1998). This might indicate a particular Australian phenomenon in terms of newspaper reporting, with an emphasis on expected victims, rather than rare victims. This is supported by Jewkes' (2015) notion of predictability that suggests that a story may be newsworthy if it is predictable as journalists can plan their reporting in advance. The possible orientation of reporting around young adult victims of violence requires further exploration.

The results further indicated that homicides involving the presence of multiple victims are more likely to be reported in Australian newspapers compared to homicides involving one victim. This is consistent with previous research and the concept of rarity. Previous research states that homicides that have multiple victims occur infrequently, but are more likely to be included in media coverage (Gruenewald, Pizarro \& Chermak 2009; Johnstone, Hawkins \& Michener 1994; Lundman 2003; Paulsen 2003; Peelo et al. 2004; Sorenson, Manz \& Berk 1998). Thus, one explanation is that homicides involving multiple victims are considered rare and consequently more newsworthy, so therefore are more likely to be reported by the media. Another explanation could be Jewkes' (2015) notion of threshold that suggests that events have to meet a level of perceived importance or drama in order to be newsworthy and a homicide with multiple victims could be perceived as important.

In addition to victim characteristics, the results indicated that a range of situational characteristics was also over-represented in the sampled articles. The mode of death from a gunshot wound was over-represented, and beating was under-represented in the sampled newspaper articles. This is consistent with previous research that found dangerousness and the risk the offender or crime poses to society to be factors in whether a homicide is included in media reporting (Gruenewald, Chermak \& Pizarro 2013). Homicides that involve guns may 
be seen as more dangerous and therefore receive more media coverage (Gruenewald, Chermak \& Pizarro 2013). This is consistent with the concept of rarity as it is more rare for the mode of death to be from a gunshot wound compared to a beating (Bryant \& Cussen 2015). Also, the 'other' category was over-represented in the sampled newspaper articles. The 'other' category contained homicides involving burns, shaking, drowning and being pushed from high places. These modes of death are rare, and may be considered particularly disturbing to the public, making them more newsworthy.

Previous literature has indicated that when a victim and offender were strangers, the homicide was more likely to be reported in the media (Buckler \& Travis 2005; Gruenewald, Chermak \& Pizarro 2013; Peelo et al. 2004; Sorenson, Manz \& Berk 1998). This study supports these findings as the results showed that homicides involving domestic or acquaintance victim-offender relationship were less likely to be reported by the media. The fear of crime literature shows that people are more fearful of stranger violence than being victimised by someone they know (Scott 2003). It may be that the media actively uses this notion of 'stranger danger' to its advantage given the 'victim-blaming' narrative that still exists within some legislative and policy frameworks (for example, defensive homicide) (Fitz-Gibbon 2012). Homicides where the victim knew the offender may be considered less newsworthy as society may not sympathise with victims who are perceived to be at least partially to blame for their own victimisation (Christie 1986).

\section{Accurate depictions of homicide}

While this study has shown inconsistencies between the sampled newspaper articles and the actual characteristics of homicide, there are also consistencies. All of the offender characteristics in the sampled newspaper articles were accurate portrayals of the actual characteristics of homicide in Australia as reported by the NHMP. This included the offender characteristics of sex, age and multiple offenders. Thus, in the current study, newspaper articles provide a relatively accurate portrayal of offenders who commit homicide in Australia.

The majority of offenders in Australia are male between the ages of 18 and 49 and are single offenders (Bryant \& Cussen 2015). These are also the characteristics that are presented in the majority of the newspaper articles. Except for offender sex (Barlow, Barlow \& Chiricos 1995), these findings are not in line with prior research, which shows that the greater number offenders, the more likely the homicide is to be covered by the media (Johnstone, Hawkins \& Michener 1994; Lundman 2003), and that young and elderly offenders of homicide are more likely to be reported in the media (Peelo et al. 2004). Thus, it appears that rarity may not be able to explain offender variables as well as it may explain victim and situational variables. Therefore, alternative explanations should be sought.

It may be that, despite globalisation, Australia is culturally different from the countries in which most media research on homicide to this date has been conducted, such as the US. This may be particularly the case in terms of the social context of homicide. First, Australia has significantly lower levels of homicide compared to the US (United Nations Office on Drugs and Crime 2011). Thus, there are fewer homicide incidents that the media have at their disposal to report on. Second, the rate of gun ownership in the US is significantly higher than in Australia (Chapman \& Alpers 2013) and research confirms cross-national variations in the nature of homicide (United Nations Office on Drugs and Crime 2011), which could explain why there are inconsistencies between the current study and previous studies conducted in the US. Alternatively, the different findings from international research could be a function of the sample. While the newspaper articles were randomly selected, it is possible that the articles sampled may 
not be a representation of the whole set of newspaper articles and selection bias may have inadvertently occurred. This suggests the need for further research to replicate this study.

What the public conceives to be true about crime is strongly influenced by information provided by the media (Chermak \& Chapman 2007). However, this study has shown that the Australian print media does not provide an accurate depiction of homicide overall, at least in regards to victim and situational characteristics. The implication of this is that if the public is provided with a distorted view of homicide, policy could be implemented that reflects this distorted view as opposed to the reality of homicide. This is because policymakers use media coverage to determine what the public opinion is concerning crime (Beckett \& Sasson 2003). For example, over-representation of female victims might result in policies and prevention strategies that inadvertently ignore the needs of male victims. Furthermore, this distortion of homicide can increase the public's fear of homicide (Reiner 2002). For example, the over-representation of stranger homicides might increase the public's fear of homicide out of proportion to the actual risks. This fear may in turn increase the public's receptiveness to tough-on-crime policies for certain types of offences (Scheingold 1991).

\section{Limitations and future research}

There are some limitations that should be noted. The study focused on newspapers and did not examine other media sources such as radio, television or online material. Newspapers were chosen for three major reasons: databases containing transcribed newspapers (for example, Factiva) facilitate data collection, newspaper articles are often used as the source for television and radio reporting of homicide (Sweetser, Golan \& Wanta 2008), and print newspaper readership rates in Australia are still relatively high despite the increase in online news subscriptions (Roy Morgan Research 2015). However, more research is needed to examine whether the findings from the current study extend to media representations of homicide within other media sources such as radio, television and online material. In particular, online environments such as social media have facilitated audience participation in shaping media content (Surette 2015; Bruns 2011) and agenda-building (see Milivojevic \& McGovern 2014). These issues need to be examined further in future research.

A second limitation is that this study's timeframe was between 1 July 2008 and 30 June 2012, which is a relatively short period. Research shows that media reporting has changed significantly over the decades (Williams 2009) and it may be important to examine media reporting of homicide within a historical context (see Fairbairn \& Dawson 2013). Some of the previous research on print media representations of homicide stems from the 1990s. Much of media reporting may have changed since these studies were conducted, including what is considered newsworthy and the regulatory frameworks within which media organisations operate. More research is required to further understand this historical context.

Also, this study was not able to conclusively determine why the results indicated that newspaper reporting of homicide provided a relatively accurate depiction of the offender characteristics of homicide in Australia compared to previous literature (which found an overrepresentation of certain characteristics, such as offender sex and age). Therefore, further research is required to examine whether these differences stem from cultural variations, sampling techniques, or other reasons.

A fourth limitation is that this study focused on skewness by quantitatively examining whether newspaper articles are overall consistent or inconsistent with official homicide data. As such, the study did not examine the narratives in newspaper articles. Peelo (2006) 
highlights the importance of qualitatively examining media at the micro level of textual analysis. Such analyses can reveal important discursive content. For example, MoncktonSmith's (2012) work shows that news reporting of cases involving men who kill their female intimate partners are often framed around narratives of romantic love as a rationalisation for homicide, whereas other narratives such as violence and coercive control are not given much prominence.

Finally, there was not enough data in the sampled newspaper articles to examine if race was a factor in determining whether a homicide is reported in the media in Australia. Race is an important determinant of newsworthiness as seen in previous international studies (Johnstone, Hawkins \& Michener 1994; Paulsen 2003; Sorenson, Manz \& Berk 1998). Given the high rate of homicide within Indigenous communities in Australia (Bryant \& Cussen 2015), future research is required to examine whether race is a factor in impacting whether a homicide is likely to be reported in the media.

\section{Conclusion}

Overall, the study suggests that newspapers in Australia do not represent homicide accurately. This is problematic, as the media can influence policymaking, tough-on-crime policies, and the public's fear of crime (Beckett \& Sasson 2003; Gruenewald, Pizarro \& Chermak 2009; Reiner 2002; Scheingold 1991). The results of this study indicated significant differences in newspaper reporting of victim and situational characteristics compared to the national homicide statistics provided by the NHMP. There was an over-representation of female homicide victims, victims under 24 and homicides involving multiple victims. In addition, homicides where the mode of death was a gunshot wound were over-represented, as well as homicides where the victim and offender were strangers. However, interestingly, the results indicated newspaper reporting of homicide provided a relatively accurate depiction of the offender characteristics of homicide in Australia. A rarity framework, the concept of 'ideal' victims, and news values assist in explaining what is considered newsworthy and, therefore, what is included in media coverage. However, while they may explain victim and situational characteristics, these concepts appear less apt to explain the newsworthy nature of offender characteristics. 


\section{References}

Barlow, MH, Barlow, DE \& Chiricos, TG 1995, 'Economic conditions and ideologies of crime in the media: a content analysis of crime news’, Crime \& Delinquency, vol. 41, no. 1, pp. 3-19.

Beckett, K \& Sasson, T 2003, The politics of injustice: crime and punishment in America, Sage Publications, California.

Boulahanis, JG \& Heltsley, MJ 2004, 'Perceived fears: the reporting patterns of juvenile homicide in Chicago newspapers’, Criminal Justice Policy Review, vol. 15, no. 2, pp. 132-60.

Brookman, F 2005, Understanding homicide, Sage, London.

Bruns, A 2011, 'Gatekeeping, gatewatching, real-time feedback: new challenges for journalism', Brazilian Journalism Research Journal, vol. 7, no. 2, pp. 117-36.

Bryant, W \& Cussen, T 2015, Homicide in Australia: 2010-11 to 2011-12: National Homicide Monitoring Program report, Australian Institute of Criminology, Canberra, viewed 1 November 2017, http://aic.gov.au/publications/current series/mr/21-40/mr23.html.

Buckler, K \& Travis, L 2005, 'Assessing the newsworthiness of homicide events: an analysis of coverage in the Houston Chronicle', Journal of Criminal Justice and Popular Culture, vol. 12, no. 1, pp. 1-25.

Chapman, S \& Alpers, P 2013, 'Gun-related deaths: how Australia stepped off “the American path”', Annals of Internal Medicine, vol. 158, no. 10, pp. 770-1.

Chermak, SM \& Chapman, NM 2007, 'Predicting crime story salience: a replication', Journal of Criminal Justice, vol. 35, no. 4, pp. 351-63.

Christie, N 1986, ‘The ideal victim’, in EA Fattah (ed.), From crime policy to victim policy, Springer, London.

Duwe, G 2000, 'Body-count journalism the presentation of mass murder in the news media', Homicide Studies, vol. 4, no. 4, pp. 364-99.

Fairbairn, J \& Dawson, M 2013, 'Canadian news coverage of intimate partner homicide: analyzing changes over time’, Feminist Criminology, vol. 8, no. 3, pp. 147-76.

Fitz-Gibbon, K 2012, 'The Victorian operation of defensive homicide: examining the delegitimisation of victims in the criminal court system', Griffith Law Review, vol. 21, no. 2, pp. 555-81.

Gekoski, A, Gray, JM \& Adler, JR 2012, 'What makes a homicide newsworthy? UK national tabloid newspaper journalists tell all’, British Journal of Criminology, vol. 52, no. 6, pp. 1212-32.

Golan, G 2006, 'Inter-media agenda setting and global news coverage: assessing the influence of the New York Times on three network television evening news programs', Journalism Studies, vol. 7, no. 2, pp. 323-33.

Grabosky, PN 1995, Fear of crime and fear reduction strategies. Trends and issues in criminal justice no. 44, Australian Institute of Criminology, Canberra.

Gruenewald, J, Chermak, SM \& Pizarro, JM 2013, 'Covering victims in the news: what makes minority homicides newsworthy?’, Justice Quarterly, vol. 30, no. 5, pp. 755-83.

Gruenewald, J, Pizarro, J \& Chermak, SM 2009, 'Race, gender, and the newsworthiness of homicide incidents’, Journal of Criminal Justice, vol. 37, no. 3, pp. 262-72.

Hinton, PR, McMurray, I \& Brownlow, C 2014, SPSS explained, Routledge, London. 
Hoffman, LH 2006, 'Is internet content different after all? A content analysis of mobilizing information in online and print newspapers’, Journalism \& Mass Communication Quarterly, vol. 83, no. 1, pp. 58-76.

Hong, SY 2008, 'The relationship between newsworthiness and publication of news releases in the media’, Public Relations Review, vol. 34, no. 3, pp. 297-9.

Jewkes, Y 2015, Media and crime, 2nd edn, Sage, Los Angeles.

Johnstone, JW, Hawkins, DF \& Michener, A 1994, 'Homicide reporting in Chicago dailies’, Journalism \& Mass Communication Quarterly, vol. 71, no. 4, pp. 860-72.

Kraska, P \& Neuman, WL 2011, Criminal justice and criminology research methods, 2nd edn, Prentice Hall, New Jersey.

Lundman, RJ 2003, 'The newsworthiness and selection bias in news about murder: comparative and relative effects of novelty and race and gender typifications on newspaper coverage of homicide', Sociological Forum, vol. 18, no. 3, pp. 357-86.

Meyers, M 1996, News coverage of violence against women: engendering blame, Sage Publications, California.

Milivojevic, S \& McGovern, A 2014, 'The death of Jill Meagher: crime and punishment on social media', International Journal for Crime, Justice and Social Democracy, vol. 3, no. 3, pp. 22-39.

Monckton-Smith, J 2012, Murder, gender and the media: narratives of dangerous love, Palgrave Macmillan, New York.

Morgan, J \& Politoff, V 2012, Victorian print media coverage of violence against women: a longitudinal study, VicHealth, viewed 7 July 2015, http://thelookout.sites.go1.com.au/sites/thelookout. sites.go1.com.au/files/PVAW Print-media-Tech Report_FINAL.pdf.

Mouzos, J 2002, Quality control in the National Homicide Monitoring Program (NHMP), Australian Institute of Criminology, Canberra, viewed 1 November 2017, https://aic.gov.au/ publications/tbp/tbp002.

Pallant, J 2013, SPSS survival manual, 5th edn, McGraw-Hill Education, London.

Paulsen, DJ 2003, 'Murder in black and white the newspaper coverage of homicide in Houston', Homicide Studies, vol. 7, no. 3, pp. 289-317.

Peelo, M 2006, 'Framing homicide narratives in newspapers: mediated witness and the construction of virtual victimhood', Crime, Media, Culture, vol. 2, no. 2, pp. 159-75.

Peelo, M, Francis, B, Soothill, K, Pearson, J \& Ackerley, E 2004, 'Newspaper reporting and the public construction of homicide’, British Journal of Criminology, vol. 44, no. 2, pp. 256-75.

Petersen, N 2016, 'Neighborhood context and media constructions of murder a multilevel analysis of homicide newspaper coverage in Los Angeles County’, Homicide Studies, vol. 20, no. 1, pp. 25-52.

Pritchard, D \& Hughes, KD 1997, 'Patterns of deviance in crime news', Journal of Communication, vol. 47, no. 3, pp. 49-67.

Quilter, J 2014, 'One-punch laws, mandatory minimums and “alcohol-fuelled” as an aggravating factor: implications for NSW criminal law’, International Journal for Crime, Justice and Social Democracy, vol. 3, no. 1, pp. 81-106. 
Reiner, R 2002, 'Media made criminality: the representation of crime in the mass media', in M Maguire, R Morgan and R Reiner (eds.), The Oxford handbook of criminology, 5th edn Oxford University Press, Oxford.

Roberts, L \& Indermaur, D 2007, 'Predicting punitive attitudes in Australia', Psychiatry, Psychology and Law, vol. 14, no. 1, pp. 56-65.

Roy Morgan Research 2015, Newspaper cross-platform audience, 12 months to June 2015, viewed 1 February 2016, http://www.roymorgan.com/industries/media/readership/newspaper-cross-platformaudience.

Scheingold, SA 1991, The politics of crime: criminal process and cultural obsession, Temple University Press, Philadelphia.

Schildkraut, J \& Donley, AM 2012, 'Murder in black a media distortion analysis of homicides in Baltimore in 2010', Homicide Studies, vol. 16, no. 2, pp. 175-96.

Scott, H 2003, 'Stranger danger: explaining women's fear of crime', Western Criminology Review, vol. 4, no. 3, pp. 203-14.

Sorenson, SB, Manz, JG \& Berk, RA 1998, 'News media coverage and the epidemiology of homicide', American Journal of Public Health, vol. 88, no. 10, pp. 1510-14.

Surette, R 2015, 'Performance crime and justice', Current Issues in Criminal Justice, vol. 27, no. 2, pp. 195-216.

Sutherland, G, McCormack, A, Pirkis, J, Vaughan, C, Dunne-Breen, M, Easteal, P \& Holland, K 2016, Media representations of violence against women and their children, viewed 1 November 2017, http://media.aomx.com/anrows.org.au/H3_2 2_Media_CONTENT_low.pdf.

Sweetser, KD, Golan, GJ \& Wanta, W 2008, 'Intermedia agenda setting in television, advertising, and blogs during the 2004 election’, Mass Communication \& Society, vol. 11, no. 2, pp. 197-216.

United Nations Office on Drugs and Crime 2011, 2011 Global study on homicide: trends, contexts, data, United Nations Office on Drugs and Crime, viewed 1 November 2017, https://www.unodc.org/ unodc/en/data-and-analysis/statistics/crime/global-study-on-homicide-2011.html

Williams, K 2009, Read all about it!: a history of the British newspaper, Routledge, London. 